\title{
Nacionalizam i razaranje društva: dometi jednog objašnjenja
}

Vjeran KATUNARIĆ

Odjel za sociologiju, Sveučilište u Zadru

vjeran.katunaric@zg.t-com.hr

- Silvano Bolčić. Razaranje i rekonstitucija društva: Srbija na prelazu u XXI vek. Beograd: Službeni glasnik, 2013, 332 str.

[M]orao je pretrpjeti sudbu svih onih koji dođu u kakav mali grad, u kojem ima mnogo usta koja govore, a malo glava koje misle.

(Victor Hugo, Jadnici)

Začuđen sam ljudskom, vremenskom, stvarnom, logičkom stranom jedne pojave koja je istodobno tako nestvarna, tako nerazumljiva i tako bezvremenska. A htio bih je prikazati na takav način da se sačuva ta istodobnost.

(Gerhard Richter, likovni umjetnik)

\section{Uvod}

Silvano Bolčić jedan je od vodećih sociologa i mislećih ljudi u Srbiji, afirmiran kao teoretičar i empirijski istraživač društvenih procesa u bivšoj Jugoslaviji i postjugoslavenskoj Srbiji. Objavio je mnogo zapaženih radova u domaćim i inozemnim zbornicima i časopisima. Najprije je radio kao suradnik Instituta ekonomskih nauka u Beogradu, a od 1975. do 2007. bio je nastavnik, odnosno profesor na Odeljenju za sociologiju Filozofskog fakulteta u Beogradu. Uz ove napomene i radi što boljeg razumijevanja autorovih ishodišta, navodimo ulomak iz njegove biografske bilješke u uvodnom dijelu knjige Razaranje i rekonstitucija društva: Srbija na prelazu u XXI vek: »Rođen sam [...] u malom rudarskom naselju Vinež, u opštini Labin, u Istri. Otac mi je najveći deo života radio kao rudar, a majka je bila domaćica [...]. Moj se otac doselio iz Slovenije u Labin, da bi radio u rudniku, i njegovi su, po etničkoj pripadnosti, Slovenci iz pograničnog područja blizu Kopra. Majka mi je rođena u malom selu pored Labina, i za sebe bi uvek rekla da je Istranka, naravno i Hrvatica. Italijansko ime Silvano jedino je što imam italijansko [...]. [O]d početka devedesetih imao [sam] potrebu da izgovorim, pre svega na 
međunarodnim naučnim skupovima [...] da sam 'po ocu Slovenac, po majci i mom mestu rođenja, Hrvat, po ženi i svojoj deci, po mestu njihovog rođenja, Srbin'. S nestankom Jugoslavije nestao je i važan deo mog identiteta« (Bolčić, 2013: 18).

Gubitak velikog dijela osobnog identiteta jedna je od mnogih posljedica urušavanja društva u kojem je supostojanje višestrukih identiteta, kao što je Bolčićev, i jednostrukih identiteta, kao što je slučaj s većinom drugih ljudi, zadugo bila normalna društvena pojava. Bolčićevo samoopažanje je i prikladan povod za bolje razumijevanje njegove, kako je naziva, »lične jednačine«. Bolčić se neskriveno ponosi svojim podrijetlom u istarskom etnokulturnom mozaiku kao svojim pluralnim »identitetskim zapisom« što ga je kasnije, školujući se i znanstveno i javno djelujući u beogradskoj sredini, diskurzivno razvio kao svoj građanski i politički kredo i kao svoj intelektualni stil. Bolčić je uvijek otvoren za dijalog i toleranciju prema drugima i drukčijima. Tako je oblikovao i svoju sociološku orijentaciju. Njegova je analiza društvenih problema višestrana, a njegovo polazište istodobno znanstveno i etičko. Sociološku spoznaju društvenih problema smatra nepotpunom ako osim teorijske i empirijske dimenzije nema i dimenziju primjene u smislu angažmana ili barem pokušaja angažmana na rješavanju problema. Možda je od sociologije pretjerano očekivati da, poput medicine, uspostavi pouzdanu dijagnozu i predloži odgovarajuću terapiju, premda je i u toj egzaktnijoj primjeni znanstvenih znanja najznanstvenija dionica procesa spoznaje podjednako teška i dijelom spekulativna kao i u sociologiji. Riječ je o otkrivanju i objašnjenju uzroka najtežih bolesti, odnosno najsloženijih društvenih problema. U Bolčićevoj knjizi ima svih elemenata tog »triptiha« znanja i, donekle očekivano, nedoumica oko objašnjenja uzroka razaranja društva. Nedoumica nema ili ima u daleko manjoj mjeri s obzirom na dijagnozu stanja razorenog društva, koja je iscrpno obrazložena i potkrijepljena empirijskim uvidima, i na prijedlog terapije koji se sastoji od niza vrlo razložnih i sadržajno sveobuhvatnih pretpostavki za rekonstituciju društva (Srbije). Pa ipak, je li moguće analitički i aplikativni dio spoznaje (društva Srbije) posve pouzdano izvoditi iz mjestimično nedostatnoga temeljnog objašnjenja uzroka razaranja jednog društva? U nekom smislu i da i ne, budući da, kao što ćemo u nastavku pokazati, Bolčić na nekim mjestima temeljno objašnjenje, u smislu posvemašnje »nacionalizacije društva«, dopunjuje ili dijelom zamjenjuje nekim drugim objašnjenjima.

\section{Razoreno društvo}

U knjizi se mogu uočiti najmanje tri varijante uzročnog objašnjenja razaranja društva Srbije, među kojima prevladava ona o »nacionalizaciji društva«. Iako ostale ne proturječe prvoj varijanti, njihova međusobna veza nije posebno određena. Sociološki se najrelevantnijom čini druga varijanta, stoga što autor uzročnike procesa razaranja društva nalazi u različitim sferama društva ispod njegove službene površine, koja je uređena zakonskim propisima, presvučena ideološkim lakom ili identificirana kao sociologijski ili pak popularno prepoznatljiva skupina ili mreža. Naprotiv, riječ je o višeslojnom i u pravilu podzemnom i bezimenom i u biti an- 
timodernom društvenom procesu. Taj se proces, da tako kažemo, napaja negativnom energijom koja izvire iz relativno brzih razaranja veza između različitih ljudi (durkheimovski rečeno, veza organske solidarnosti), u korist istovrsnih ljudi, tj. pojedinaca i skupina koji teže unutrašnjoj homogenizaciji i vanjskoj isključivosti (mehaničkoj solidarnosti) u ime bilo kojeg načela ili cilja.

U trećoj varijanti uzročnog objašnjenja Bolčić preuzima, uz kritičke ograde, Popperovu ideju otvorenog društva kako bi pokazao da se nasuprot tome razvija jedno antimoderno i zatvoreno društvo čijem se trajanju još ne vidi kraj, ali ipak smatra da je zatvoreno društvo neodrživo na duži rok.

Dotle glavna varijanta uzročnog objašnjenja kao glavni izvor razaranja društva (Srbije) vidi u prerastanju nacionalizma u totalitarni društveni fenomen koji guta društvo. Bolčić je bez sumnje impresioniran snagom i prodornošću nacionalizma, posebno nacionalizma u Srbiji. Iako su zbivanja u Srbiji svojstvena i drugim državama bivše Jugoslavije, autor smatra da je društvo Srbije u tom pogledu i netipično. Naime, nigdje drugdje, prema njegovu mišljenju, posljedice razaranja društva, uključujući posljedice ratova bivše Jugoslavije, nisu toliko izražene kao u Srbiji. Ta se tvrdnja može na trenutak učiniti pretjeranom, uzme li se u obzir, na primjer, slučaj Bosne i Hercegovine. S druge strane, treba imati na umu da su potresi $u$ društvu Srbije, od osamdesetih do kraja devedesetih godina 20. stoljeća, proizveli udarne valove koji su se proširili ostalim dijelovima bivše Jugoslavije i kao da su se potom uvećanom snagom, poput bumeranga, vratili u društvo Srbije (pad Miloševića, otkidanje većeg dijela Kosova uz potporu NATO-a, EU-a i SAD-a), što je produžilo razaranje društva.

U nastavku ovog osvrta sažeto ćemo prikazati sadržaje i glavne argumente knjige, a nakon toga raspraviti o dometu objašnjenja raspada Jugoslavije kao posljedice »nacionalizacije društva«, uzimajući pritom u obzir dva konteksta. Prvi kontekst prethodi »nacionalizaciji« društ(a)va na tlu bivše Jugoslavije osamdesetih, a odnosi se na cijelo razdoblje od završetka Drugoga svjetskog rata do početka osamdesetih, kad su, prema Bolčićevu mišljenju, politički sukobi na nacionalnoj osnovi, u usporedbi s eksplozijom nacionaliz(a)ma osamdesetih, bili iznimka. Drugi kontekst, u kojem se nastavlja proces »nacionalizacije društva«, odnosi se na razdoblje od devedesetih do danas. U tom razdoblju nastaje društvo Srbije u okviru samostalne države, ali se ono, prema Bolčićevu mišljenju, dalje urušava. Podrobna analiza tog konteksta zauzima najveći dio knjige.

$\mathrm{S}$ obzirom na takav poredak tema i argumenata, nameću se dva pitanja. Prvi možemo uvjetno nazvati teleologijskim, a odnosi se na eventualni kontinuitet između osamdesetih i prethodnog razdoblja. Mogu li se izvori »nacionalizacije društva« bivše Jugoslavije i Srbije u njezinu sklopu naći prije osamdesetih? Bolčić odbacuje tu mogućnost pa prethodno razdoblje, barem u slučaju Srbije, ne uzima kao »pripremu« za nacionalizam osamdesetih. Stoga se nameće pitanje o izvorima nacionalizma općenito i u Srbiji posebno, o čemu autor ne daje posebna objašnjenja. Drugo se pitanje tiče prediktivnosti uzročnog objašnjenja, naime koliko je nacio- 
nalizam suzio ili blokirao razvoj društva Srbije ili njegovu moguću rekonstituciju. Je li proces »nacionalizacije društva«, čije je postojanje nesumnjivo, isprepleten s nekim drugim (uzročnim) procesima (razaranja društva)? Može se reći da Bolčić ni tu mogućnost ne odbacuje niti dočekuje nespreman. »Nacionalizaciju društva« shvaća kao složen proces, koji se odvija u svim sferama društva, premda nije posve jasno jesu li drugi procesi razaranja društva od početka nacionalno specifični ili nacionalistički ili se odvijaju istodobno s »nacionalizacijom društva«, na primjer kao njezini katalizatori.

Problem razlučivanja nacionalizma od društvenih procesa koji se odvijaju pod njegovim imenom, iako ne moraju imati to podrijetlo pa ni cilj, kao što je primjerice pogodovanje u privatizaciji poduzetnicima koji su sunarodnjaci, iste nacionalne pripadnosti, nipošto nije problem samo u ovoj knjizi. Neujednačena ili ograničena objašnjenja nacionalizma svojstvena su brojnim suvremenim autorima i djelima. Neki u strategiji argumentacije pribjegavaju redukcionizmu pa naciju smatraju proizvodom medijskog oblikovanja društva i vremena u znaku istodobne pripadnosti zamišljenoj zajednici. Drugi su pak skloni eklektičnosti i relativizmu, a treći kontekstualizmu. ${ }^{1}$ Zbog toga opada domet objašnjenja nastanka ili širenja nacionalizma pa se danas zaista ne može ustanoviti jedinstveni teorijski okvir za sve uvjete (ne)pojavljivanja nacionalizma, kao ni to što se sve (ne) ubraja u nacionalizam. Doda li se tome neizbježan utjecaj ideologija na rasuđivanje u društvenoj znanosti (usp. Kalanj, 2010), koji je osobito izražen u vrijeme kad se nacija (samo) predstavlja kao društvo i u vrijeme većih društvenih promjena, kao što je tranzicija, može se zaključiti da u tom slučaju poluistina često zamjenjuje istinu. No, moć autonomnog rasuđivanja individualna je prije nego karakteristika neke znanosti ili struke, da ne govorimo o ustanovi, stranci ili društvenoj klasi. Ovdje je, dakako, riječ o Bolčićevoj moći rasuđivanja. Iako njegova knjiga govori o tranzicijskom kontekstu, nad kojim su se nadvile moćne ideologijske sugestije (najpoznatija glasi da je riječ o prijelazu iz autoritarnog u demokratski poredak i iz neučinkovite socijalističke u učinkovitu tržišnu ili kapitalističku ekonomiju) te, iako je svjestan činjenice da na svakoj njegovoj važnijoj tvrdnji o društvu stoji teret cijelog spektra različitih svjetonazora, te, iako sam priznaje da ne može pouzdano suditi o »vlastitoj nepristranosti«, može se slobodno reći da je utjecaj ideologija u igri u ovom slučaju sveden na minimum. ${ }^{2}$ To se naročito dobro može vidjeti usporedimo li Bol-

\footnotetext{
${ }^{1} \mathrm{O}$ Andersonovu poimanju nacije kao društva preslikanog u roman ili novine, sociobiologijskoj kombinaciji genetskih i kulturnih dimenzija pripadanja i Gellnerovu kontekstualizmu, kojim objašnjava činjenicu da se nacionalizam pojavljuje samo u otprilike desetak posto slučajeva u odnosu na ukupan broj nacija ili etničkih skupina u suvremenom svijetu, vidjeti opširnije u: Katunarić, 2003.

${ }^{2}$ Bolčić je svoju kritiku ondašnje vladajuće (partijske) ideologije izložio početkom osamdesetih, sudjelujući u radu »Kraigherove komisije« i izradi Stabilizacijskog programa (Bolčić, 2013: 267-271). Što se tiče njegovih kritičkih odmaka od novih hegemonijskih ideologija, od nacionalističke do menadžerske, njima knjiga obiluje.
} 
čićevu knjigu s većinom radova na temu tranzicije, posebno garniranima svojedobnim »egzodusom« ekonomskih stručnjaka iz marksizma ili »dogovorne ekonomije« u neoliberalizam ili ekonomiju »slobodnog tržišta«. ${ }^{3}$ Unatoč tom »samoispravljanju«, novo etabliranje stručnjaka nije rezultiralo koherentni(ji)m poimanjima razvoja. Čini se, naprotiv, kao da »tranzicijska« misao drhti pred novim autoritetima, uslijed čega ideje, poput mode, brzo zastarijevaju. Bolčić isto tako primjećuje pometnju u novome »prijelaznom roku«: »Teško je u ovom vremenu, i na dojučerašnji način, biti liberal, konzervativac, levičar ili desničar, marksista, socijaldemokrata, vernik (bilo koje vrste), nacionalista, kozmopolita i dr.« (Bolčić, 2013: 275).

Ta musilovska parafraza (o intelektualcu bez svojstava) ne odnosi se samo na današnju Srbiju, barem ne za čitatelje knjige izvan Srbije, nego i široki krug tranzicijskih zemalja i njihovih u međuvremenu provincijaliziranih društvenih elita. Česta promjena stajališta jedan je od najpouzdanijih znakova provincijalizma, u čemu naravno najviše prednjače političke elite, ili njihov dobar dio, koje preuzimaju »haiderovski« stil. Za relativno kratko vrijeme spremni su promijeniti ideološku poziciju jednu za drugom - dakako s ciljem da privuku što više potencijalnih glasača. Tako nešto znanstvenik ne smije činiti ${ }^{4}$ i Bolčićeva je knjiga pisana stilom i po sadržaju tako da se na mnogo načina obrađuje jedna tema, da je ne može »kooptirati« nijedna politička stranka ili pokret.

\section{Od uzroka razaranja do aktera rekonstitucije društva}

Taj Bolčićev magnum opus plod je dugogodišnjega sociološkog bavljenja društvom. Sadržaj knjige je opsežan i obuhvaća ključne teme koje se odnose na strukturu i dinamiku (globalnog i lokalnog) društva. Pritom poduzima smion pokušaj teorijske sinteze svojih socioloških spoznaja, objašnjavajući glavne društvene procese: razaranje društva i nacionalizaciju društva. Polazeći od definicije tih i srodnih sociologijskih pojmova uz odabir prikladnih teorijskih okvira, Bolčić je formulirao osnovne hipoteze i potkrijepio ih, koliko je mogao, empirijskim podatcima. Iz tog je nastala osebujna sociološka panorama društva Srbije prije i nakon devedesetih godina.

Knjiga započinje definiranjem »razorenog društva«. Uspoređujući ga s nizom sličnih pojmova (dezorganizacija, dezintegracija, involucija, anomija), Bolčić njegovu heurističku prednost slikovito prikazuje kao »urušenu kuću«, mjesto u kojem siguran boravak nije moguć. Stanje razorenog društva opisuje i kao »nemogućnost stvaranja delatno sposobnih velikih društvenih koalicija, kao i nemogućnost uspostavljanja onog stepena društvene suglasnosti (ili društvene hegemonije o kojoj je govorio A. Gramsci), što je preduslov za uobličavanje jasne strategije dugoročnog

\footnotetext{
${ }^{3} \mathrm{Na}$ primjeru tranzicije u Hrvatskoj vidjeti opširnije u: Katunarić, 2007.

${ }^{4}$ Weber je naglašavao da se političar mora dopasti što širem krugu ljudi i zbog toga ne mora voditi računa o proturječnosti svojih izjava, dočim se znanstvenik, što je sinonim za misaonu dosljednost, ne mora niti može dopadati širem krugu ljudi (Weber, 1964).
} 
razvoja i uspešnog društveno-sistemskog razvoja« (Bolčić, 2013: 27). Empirijskih uvida o toj nemogućnosti ima napretek: od stanja na Kosovu preko nepoštovanja pravnih propisa i širenja izvaninstitucionalne ekonomije do siromašenja većine stanovnika i njihovih sumornih pogleda na budućnost.

Nakon toga u knjizi slijedi kratak i teorijski ključan dio u kojem Bolčić objašnjava uzroke razaranja društva. Dajući do znanja da je riječ o hipotetskom objašnjenju, napominje da, kao i mnogi sociolozi, pa i oni koji polaze od (kasnog) Poppera, ni po kojem modelu opovrgavanja nije moguće posve provjeriti istinitost hipoteze. Stoga svoje argumente izlaže uz dužan oprez s obzirom na mogućnost redukcionizma. S tog gledišta, ratove bivše Jugoslavije Bolčić vidi (i) kao katalizatore društvenog razaranja, čime je dovršeno rastakanje legitimnosti bivše savezne države i multietničkog društva na samostalne etnonacionalne cjeline. U tim ratovima vidi i jedan dublji razorni proces, »radikaln[u] distorzij[u] odnosa prema osnovnim ljudskim vrednostima«. Teško je, međutim, pobliže odrediti kada započinju ti procesi. Što se tiče »unutrašnjih« protagonista razaranja društva, ponajprije u političkoj sferi, očito je da njihovo djelovanje započinje osamdesetih. Stoga Bolčić posljednju dionicu analize uzroka razaranja društva Srbije posvećuje meteorskoj karijeri i političkom stilu Slobodana Miloševića, koji je u dobroj mjeri (i »po potrebi«, kako ironično primjećuje) bio izvaninstitucionalan. Zajednički je nazivnik procesâ razaranja društva, prije i nakon rata, »nacionalizacija društva«. Bolčić ga pobliže prikazuje u prvom dijelu knjige u kojem društvo Jugoslavije i u njegovu sklopu društvo Srbije označava kao »razdrobljeno«, a na jednom mjestu i kao »urušeno« (Bolčić, 2013: 95), čime ponešto odstupa od stupnjevitog označavanja cijeloga procesa. ${ }^{5}$ Ipak je mnogo važnije što društveno stanje iz kojeg je uslijedio raspad jugoslavenske države pripisuje ukrštanju utjecaja triju sustava (moći): službenog (koji proizlazi iz zakona i propisa), realpolitičkog (proizlazi iz svakodnevnog djelovanja političkih moćnika) i sistema izbjegavanja propisa (»kojim su se svi služili«, očita persiflaža anomije). Iako heuristički poticajno i pojmovno razrađeno, to obrazloženje nije, na žalost, sustavno primjenjivano u knjizi pa ostaje nejasno jesu li ti ili nominalno prerušeni »sistemski mehanizmi« nastavili (na isti način) rovariti i nakon raspada Jugoslavije i propasti socijalizma. Iako za takav zaključak nema izravnog uporišta u knjizi, može se primijetiti, a i nije ni u neskladu s Bolčićevom perspektivom, da nijedna verzija društva Srbije, kao ni drugih društava na prostorima bivše Jugoslavije, nije odgovarala njihovim ustavnopravnim okvirima, a normativni su poredak potkopavali u biti isti koruptivni mehanizmi (tako je na više mjesta u knjizi riječ o korupciji u suvremenoj Srbiji, što je nesumnjivo jedan od glavnih neformalnih mehanizama razaranja normativnog okvira društva).

\footnotetext{
${ }^{5} »$ Urušena kuća« pojavljuje se, kao što je prije napomenuto, kao ukupan rezultat razaranja društva (Srbije) do danas, a ovdje se čini da označava stanje iz osamdesetih, kao da je zajednička »kuća« već tada bila nepogodna za stanovanje.
} 
Iz autorovih analiza konteksta osamdesetih stječe se dojam da posljednje desetljeće druge Jugoslavije vidi kao razdrobljeno i urušeno, a društvo samostalne Srbije kao razoreno. Taj cjelokupni mehanizam podsjeća na mlin(ac) koji melje »krupno« i »sitno«, koji graniči s centrifugom, metaforom kojom se u kritičkoj političkoekonomijskoj literaturi označavaju razorni učinci nekontroliranog širenja kapitalističkih tržišta (usp. Flaschel i Luchtenberg, 2012).

Poglavlje pod naslovom »'Nacionalizacija' postjugoslovenskih društava i njene posledice« (Bolčić, 2013: 112-124) u knjizi je konceptualno najvažnije za profiliranje glavnoga uzročnog objašnjenja. Bolčić ustvrđuje, između ostalog, kako sama činjenica da je kod međunarodnih stručnjaka osamdesetih godina interes za Jugoslaviju, kao domovinu radničkog samoupravljanja, znatno opao, govori o propasti tog projekta. Nakon toga su u prvi plan došli ratovi s početka devedesetih, pa ispada da su osamdesete bile priprema za »nacionalizaciju« ili »etnokratsku konstituciju« društva (Bolčić, 2013: 113). Autor također primjećuje da etnonacionalizam nije toliko došao do izražaja u drugim istočnoeuropskim društvima i da su se ta društva više posvetila društveno-ekonomskoj, sistemskoj tranziciji, unatoč činjenici što su i u njima, kao i bivšoj Jugoslaviji, građani na prvo mjesto stavljali svoju nacionalnu pripadnost, a ona je bila i službeno priznata kategorija pripadnosti.

Šteta je što autor u daljnjim razlaganjima značenjâ »nacionalizacije društva« najviše problematizira zdravorazumska shvaćanja o podrijetlu i oblicima nacionalizma na prostorima bivše Jugoslavije, ${ }^{6}$ a mnogo manje teorijske ili empirijske radove na tu temu, kojih je mnogo, a neki se u velikoj mjeri podudaraju s Bolčićevim poimanjem »nacionalizacije društva« (o čemu više u posljednjem dijelu osvrta). Ukratko, svi se aspekti društvenog života, od politike i ekonomije do znanosti i školstva, »nacionaliziraju«, pa i odnosi »prema osnovnim ljudskim vrednostima, poštenju $i$ čovekoljublju«. Ta je semantička bujica prožela i društvenu svakodnevnicu i dovela do toga da se i kriminal proglasi nacionalno korisnom stvari (Bolčić 2013: 119), čime autor vjerojatno aludira i na počinjene zločine u vrijeme ratova bivše Jugoslavije. Bolčić također upozorava da prerastanje nacionalizma u totalizirajući proces još nije završen, a da će promjene na bolje biti moguće tek nakon sloma takvih režima, posluživši se analogijom s denacionalizacijom-denacifikacijom u Europi nakon Drugoga svjetskog rata.

Neki od idućih dijelova knjige posvećeni su različitim temama, među kojima neke nisu u izravnoj vezi s glavnom temom. Među onima koje jesu valja istaknuti: razaranje civilnog društva u Srbiji, društvene nejednakosti, odnosi (političke) moći, odnosi u sferi rada i ekonomije, odljev mozgova i, napokon, ali i najrelevantnija, »terapeutska« tema, s obzirom na dijagnozu razorenog društva, a to su procesi i akteri rekonstitucije društva Srbije na novim osnovama. Prije sažetog prikaza autorovih gledanja na mogućnosti novih procesa s novim glavnim akterima, valja po-

\footnotetext{
${ }^{6}$ Tako se tvrdnja da se »nacija [...] poima kao socijalni entitet koji postoji pre društva« ne odnosi na referencu iz odgovarajuće teorijske literature (npr. Hastings, 2003 [1997]).
} 
novo naglasiti da u drugom dijelu knjige Bolčić uvodi Popperov pojam otvorenog društva kao svrhoviti model nasuprot postojećem nacionaliziranom i razorenom društvu, koje dosta često naziva, parafrazirajući Poppera, zatvorenim društvom. Ipak Bolčić otvoreno društvo, danas klasično mjesto liberalne kritike totalitarizma, uzima sociološki skrupulozno i upozorava da je svugdje društvo ispresijecano nejednakostima i da je svaka moć, kao što uostalom upozorava i Popper, potencijalno opasna za slobodu ljudi, pa tako i koncentrirana ekonomska moć, uz (Bolčićevu) napomenu da su Popperova razmatranja o društvenoj moći fragmentarna i dosta uopćena i nekonkretizirana, da suviše očekuje od institucija političke demokracije, a ne od stvarne mogućnosti društvene kontrole (odozdo) sustava moći (Bolčić, 2013: 166-168). Teško je ustanoviti izbija li u potonjoj opaski na račun Popperova povjerenja u etablirane demokratske sustave na vidjelo Bolčićeva ranija bliskost $\mathrm{s}$ idejama neposredne demokracije, koliko-toliko prisutnima u praksi radničkog samoupravljanja u bivšoj Jugoslaviji. No, na tu moguću asocijaciju upućuje njegovo glavno kritičko zapažanje o zatvorenosti društva Srbije. Društvo je zatvoreno, tumači autor, upravo zbog toga što u njemu glavnu ulogu i utjecaj imaju snage »nekontrolabilne moći«, »moćnici [koji] ne strepe od sankcija za zloupotrebu moći« (Bolčić, 2013: 172). Bolčić napominje da je takav nekontrolabilan sustav moći postojao i u vrijeme Titove Jugoslavije. I bez autorova »dopuštenja« moglo bi se dodati da ista prosudba vrijedi i za suvremeni kapitalizam čija je (nad)moć dosegnula apsolutističku razinu u usporedbi sa zapadnim kapitalizmom osamdesetih, ekonomijom države blagostanja, koja je u velikoj mjeri izgrađena na temelju široke društvene suglasnosti.

Snage koje su razorile i još uvijek razaraju društvo Srbije imaju potporu u svjetskom okruženju u kojem globalni procesi dovode u pitanje sve dosadašnje modele razvoja i proizvode sve češće krize, od financijskih do političkih - konstatira Bolčić na početku posljednjeg poglavlja pod naslovom »Bitne pretpostavke i šanse za rekonstituciju društva Srbije« (Bolčić, 2013: 276-290). Nasuprot tim tendencijama, iznosi nekoliko ključnih pretpostavki o uvjetima raskida s »kontinuitetom« devedesetih, za koji smatra da još uvijek ima dubokih tragova u Srbiji. Na kakvim bi se novim pretpostavkama moglo ili trebalo graditi društvo Srbije? Na prvom je mjestu prevladavanje »nacionalizacije društva«, osobito kad je riječ o Kosovu. Prvi pouzdani znak početka procesa »denacionalizacije« Bolčić očekuje od »svakodnevne reafirmacije ustavnog statusa građanina«. Druga pretpostavka odnosi se na ekonomsku rekonstituciju, ističući da se rekonstitucija ne bi smjela odvijati u smislu ekonomizma, svođenja razvojnih na tehnička (uglavnom makroekonomska) pitanja. Umjesto ekonomizma preporučuje široku kontekstualizaciju ekonomskog procesa, budući da je ekonomija dio društva, a ne obratno (Bolčić se poziva na radove Marka Granovettera o »uklopljenosti« /embeddedness/ ekonomije u društvo). S tim u vezi upućuje na važnost stabiliziranja društveno-političkih prilika, što pogoduje ekonomskim ulaganjima. Također predlaže da se osim za globalna proizvodi i za lokalna tržišta uz veći udio lokalnih u odnosu na državne agencije. Treća se pret- 
postavka nastavlja na prethodnu, a tiče se uređivanja vlasničkih odnosa uz uvjete da se jasno odrede titulari vlasništva i dade veći udio mješovitim oblicima vlasništva osim čisto privatnih i državnih. Četvrta je pretpostavka pretvaranje politike u »djelatnost usmjeravanja društva«, za što je nužna pozitivna selekcija kadrova na svim razinama uz široku demokratsku participaciju i potporu sfere civilnog društva. U uskoj vezi s tom je peta pretpostavka moralne obnove jednog već duboko demoraliziranog društva, čemu je glavni uzročnik dugotrajna negativna selekcija kadrova. $\mathrm{Na}$ isto se pitanje odnosi posljednja u nizu pretpostavki, a to je potreba za društvenom reafirmacijom ljudi od znanja, meritokracijom u pozitivnom smislu riječi, ljudi koji osim znanja imaju i moralni habitus, ponajprije razvijen smisao za društvenu odgovornost s obzirom na posao koji obavljaju.

Vjerojatno se malo tko među sociolozima ne bi složio s iznesenim pretpostavkama, budući da u najboljem svjetlu prikazuju raspon mogućnosti angažmana sociologa na rješavanju društvenih problema. Vjerojatno će i većina čitatelja taj dio Bolčićeve knjige ocijeniti kao najprimjereniji sociološkom profilu djela. Neki drugi dijelovi, prije svega prva dva u kojima je izloženo objašnjenje o uzrocima i posljedicama razaranja društva putem njegove »nacionalizacije«, nešto su upitnija po svojim dometima, što zaslužuje poseban komentar.

\section{Ograničeni eksplanatorni domet »nacionalizacije društva»}

Kritičke primjedbe u nastavku ne zasjenjuju dobre kvalitete ove knjige. Knjiga donosi rijetku i uglavnom uspjelu sintezu spoznaja o predtranzicijskom i (post)tranzicijskom društvu Srbije, društvu koje je bilo epicentar velikih društvenih potresa na prostoru bivše Jugoslavije, čije se posljedice osjećaju i danas. Bolčić na više načina obrazlaže svoje viđenje suvremenog društva Srbije i društvenih procesa koji su mu prethodili s tim što se u njegovim obrazloženjima ponajviše ogleda skrupuloznost spram neistomišljenika, kojih je mnogo i njihovi argumenti uglavnom nisu racionalne prirode, osobito kad je riječ o motivima i ciljevima nacionalne mobilizacije. Bolčić bolje od mnogih autora opisuje što se i zbog čega zbiva u postojećem društvu. On je otvoren spram drugih mišljenja koje brzo i točno razumije, a svoje tvrdnje, iako kristalno jasne, varira na nekoliko načina, čineći ih pristupačnima i nesociološki obrazovanim čitateljima. Jedino nedostaju neki elementi za izgradnju vlastite teorijske pozicije s obzirom na (hipo)tezu o »nacionalizaciji društva«.

Prvo je pitanje je li (hipo)teza o »nacionalizaciji društva« dovoljna? Pitanje je osobito važno imaju li se na umu blokade društvenog i ekonomskog razvoja unutar već »nacionaliziranog društva«, koje su toliko slične blokadama u multinacionalnom društvu Jugoslavije, koje Bolčić opisuje (u svojoj, kako smo je na početku osvrta označili, drugoj varijanti uzročnog objašnjenja), kao proizvod subinstitucionalnih, pa i anomijskih, procesa iz kojih izrasta naddruštveni i nekontrolabilni sustav moći. Te blokade, drugim riječima, ne moraju biti specifično srbijanske, odnosno nacionalne. Stoga nije izvjesno da bi »denacionalizacija«, odnosno »internacionalizacija« sustava moći, prije svega vlasničke i/ili upravljačke elite, nužno 
potkopala nedemokratski sustav. Sovjetski Savez i socijalistička Jugoslavija u najvećem dijelu povijesti, Međunarodni monetarni fond, Svjetska banka, upravo kao i srednjovjekovna aristokracija, da se ne govori o multinacionalnim kompanijama, predstavljaju utvrde moći koje su na ovaj ili onaj način (bile) multinacionalne. ${ }^{7}$ S druge strane, Bolčić u obrazlaganju uvjeta rekonstitucije društva Srbije, osim »denacionalizacije«, ističe i druge uvjete, uključujući novo spajanje meritokracije i (neposredne) demokracije. Čini se da bi, možda analogno tome, valjalo proširiti i objašnjenje uzroka porasta nacionalizma u bivšoj Jugoslaviji osamdesetih, što Bolčić djelomično i čini zapažanjem da prije tog razdoblja nije bilo (skoro) ničega u jugoslavenskom društvu što bi upućivalo na nacionalistički rasplet. Odakle je onda nacionalizam izbio na površinu, iz kojih dubljih slojeva društvenopovijesnog procesa? Valja pretpostaviti da nacionalizam izvire iz žarišta društvene moći koja su naknadno (nacionalistički) preimenovana, a kolektivni identitet tih skupina ili mreža dotad je bio drukčiji, a možda su (zbog razumljivih razloga) bile posve anonimne.

U tom je smislu vrlo instruktivna rasprava Rogersa Brubakera o etničnosti koja nije nužno, ili nije uvijek, grupni fenomen. Između ostalog Brubaker upućuje na nastanak Oslobodilačke vojske $\operatorname{Kosova}^{8}$ iz jedne banalne skupine, službeno obilježene kao kriminalne, koju je i većina kosovskih Albanaca doživljavala kao takvu. Ona je vremenom prerasla u nacionalno-patriotski pokret i službenu vojsku najvećeg dijela kosovskih Albanaca i utjecajnog aktera na kosovskoj političkoj sceni (Brubaker, 2002). Na osnovi tog primjera, sličnog mnogim drugim kad je riječ o genezi nacionalizma, ${ }^{9}$ Brubaker dokazuje da obilježavanjem pojedinih skupina ili mreža ili pak banalnih sukoba etničkim ili nacionalnim oznakama dolazi do etnifikacije/nacionalizacije društva, uključujući dakako sferu političke moći. Izvanredno pronicljiva i jedna od pionirskih na tu temu, još ranija od Brubakerove, rasprava je Silve Mežnarić o političkom preimenovanju kriminalnih djela na Kosovu, a radilo se o silovanju žena (srpske nacionalnosti), u »genocid nad srpskim narodom« (Mežnarić, 1993).

Da je i Bolčić na tragu takve dekonstrukcije nacionalizma, pokazuje već spomenuto mjesto u knjizi gdje proces razaranja društva opisuje kao posljedicu djelovanja podzemnih, moćnih i u osnovi anonimnih sila, koje društvo žele preoblikovati u korist manjega, a na štetu većeg dijela društva. Valja se prisjetiti i analize s donekle sličnom poantom Veljka Rusa i Frane Adama, iako tema nije nacionalizam. Njihova je analiza pokazala kako je hegemonijska (meta)moć u

\footnotetext{
${ }^{7}$ Multinacionalne, premda ne i multikulturne u smislu (ne)tolerancije spram drugih svjetonazora, osobito s obzirom na mogućnosti izbora načina razvoja društva.

${ }^{8}$ Brubaker analogno opisuje nastanak Irske republikanske armije i Kurdske radničke partije.

${ }^{9}$ Dovoljno je spomenuti nemali broj pojedinaca i skupina u Hrvatskoj devedesetih godina koji su se busali u prsa svojim hrvatstvom da bi se kasnije, što putem nezavisnih medija što na sudovima, pokazalo da se radilo o kriminalcima.
} 
bivšoj Jugoslaviji »probila lupu« (pod čime se podrazumijeva normativni okvir institucije) samoupravne radne organizacije i tom organizacijom zavladala (Rus i Adam, 1989).

Uza sve to ipak se ne može posve isključiti pretpostavka da nacionalizam nije ili nije samo konjunkturni fenomen (kako, na primjer, misli i Brubaker), nego i izraz neke dublje i dugotrajne (primordijalne) matrice društvene strukture i kolektivnog identiteta, koja se u kriznim razdobljima preoblikuje, širi i prodire u ključne društvene ustanove i svakodnevni život, proizvodeći štetne, nefunkcionalne, sukobe i blokirajući daljnji razvoj društva, ponajviše društava na periferiji suvremenog kapitalizma. Ako je tomu tako, onda bi produktivniju kariku između nacionalne kulture i transnacionalnog demokratskog sustava trebalo tražiti na neobičnom mjestu, u glasovitoj Lenjinovoj formulaciji da sovjetska kultura mora biti »nacionalna po svojoj formi i socijalistička po sadržaju« (Lenjin, 1977; usp. Herzog, 2010), pod uvjetom da se prevladaju svođenja nacionalne kulture na folklornu tradiciju i socijalizma na državno-partijsku diktaturu. Srpska i druge nacionalne kulture imaju mnogo univerzalističkih sadržaja i autora (izbor bi morao vjerojatno biti mnogo širi nego, na primjer, u »zajedničkim osnovama« školskog programa u drugoj Jugoslaviji), a socijalistička misao imala je i još uvijek ima, što pokazuje i dobar dio Bolčićeva djela, pozitivan odnos prema liberalnoj demokraciji. ${ }^{10} \mathrm{U}$ svakom slučaju, sociolozima socijalizam, iako danas predstavlja, kako bi rekao Bolčić, primjer neuspješnog društva, ne bi trebao postati tabu-temom (prema ukusu suvremenih hegemonijskih ideologija, kao što je neoliberalizam ili fašizam pod novim nazivima i zastavama). Kritika socijalizma nije ni prije bila zabranjivana, barem ne među ondašnjim jugoslavenskim sociolozima, kao što današnjim srbijanskim, hrvatskim, slovenskim i drugim sociolozima u novim državama na tlu bivše Jugoslavije, kapitalizam ne predstavlja ideološki fetiš, ponajmanje Silvanu Bolčiću.

Što se pak tiče konceptualizacije nacionalizma kao uzročnog procesa s ograničenim dometom na (dez)integraciju društva, Bolčić je u knjizi iznio zapažanje koje se može uzeti kao motiv za širu komparativnu analizu sukoba u multinacionalnim državama. On ističe da su se za razliku od Jugoslavije, Sovjetski Savez i Čehoslovačka raspali na miran način, čime opravdano ukazuje na važnost izučavanja specifičnosti političkog konteksta pojedine multinacionalne države (u ovom slučaju čine se najvažnijim različiti stilovi političkih vođa u tim zemljama).

\footnotetext{
${ }^{10}$ Uostalom, pozitivan odnos prema liberalnoj demokraciji imao je i Marx. Premda je prezirao licemjerje građanske demokracije, napose parlament kao njegovu temeljnu ustanovu (pogođeni diktaturom financijskog kapitala danas tu osudu možemo bolje razumjeti nego prije), nije pomišljao da bi proleterska država bila nedemokratska politička diktatura, paravan za diktaturu »marksističke partije«. Način na koji je u svojim ranim radovima objašnjavao komunizam kao (antikapitalistički) pokret, ali ne i željeni oblik ljudskog društva, tj. socijalizam (Marx i Engels, 1978: 283), pruža ključ za razumijevanje moguće preobrazbe jednopartijskog u višestranački demokratski socijalizam, sličan skandinavskoj državi blagostanja od šezdesetih do osamdesetih godina.
} 
Dodamo li toj usporedbi, međutim, usporedbu s multinacionalnim federacijama na osnovama liberalne demokracije i kapitalizma, u prvom redu Kanadom, Belgijom, Velikom Britanijom (s nacionalističkim težnjama u Škotskoj, Wellsu i Sjevernoj Irskoj), Španjolskom (s Katalonijom i Baskijom), Švicarskom (s jednojezičnim kantonima - njemačkim, francuskim, talijanskim i retoromanskim), može se izvući zaključak da su te složene države daleko stabilnije od bivših socijalističkih i drugih autoritarno vođenih multinacionalnih država (Šri Lanke, Indonezije, Iraka...). Pa ipak, ni objašnjenje njihove stabilnosti u liberalnom ključu nije dovoljno, osobito ne predviđanje, unatoč uglednim autorima koji podržavaju liberalni koncept, koji smatraju, poput »liberalnog funkcionalista« Ernesta Gellnera (Gellner, 1998 [1983]), da je riječ o sredinama koje su demokratski sazrele u toj mjeri da svoje nesporazume rješavaju isključivo proceduralno, u skladu s institucionaliziranim demokratskim normama, prije svih referendumom i redovnim višestranačkim izborima. Vrlo je vjerojatno, međutim, da njihovoj stabilnosti presudno pridonosi još jedan element, a to je prethodno spomenuta kapitalistička (tržišna) centrifuga. U slučaju bivše Jugoslavije rad centrifuge tek se nazirao, a danas se njegove posljedice u ovdašnjim postsocijalističkim državama vide mnogo jasnije, ponajviše zbog odumiranja tek nedavno stečene suverenosti. Suverenost opada to brže što su države više integrirane u globalno tržište, ili su, poput Slovenije i Hrvatske, postale članicama Europske unije kao osebujnoga monetarno-tržišnog saveza starih i novih demokracija. Centrifuga čini povratak u krilo nacionalne države, o čemu sanja dobar dio nacionalnih desnica, a i dio ljevice, sve teže ostvarivim pa i nemogućim. Iznad svega valja držati na umu vjerojatno najvažniju ekonomsku činjenicu na koju ukazuju rezultati neuspjelih referenduma za odcjepljenje u Kanadi (Québec), Škotskoj, na neki način i u Belgiji. Većina birača, koji su meta secesionističkih stranaka, svoj ekonomskoracionalni interes (još uvijek?) ne vide u odcjepljenju od postojećih država. Dakako, njihov interes umnogome ovisi o ekonomskoj uspješnosti dotične države. Međutim, nakon urušavanja države blagostanja na Zapadu i njezina pandana na bivšem Istoku, značenje ekonomskog uspjeha doktrinarno je suženo na povoljne uvjete za ulaganja s kojima se brzo stječe profit. Dotle tekuća politika koja tomu pogoduje skupa s »nezavisnim« medijima napadno prešućuje rastuću nezaposlenost i siromaštvo ili ih, u najboljem slučaju, pripisuje nesposobnosti lokalnih političara ( $\mathrm{u}$ »privlačenju stranog kapitala«). Hoće li takav karikaturalan »uspjeh« na jednoj strani na drugoj strani širom otvoriti vrata prodoru »pitomih « $\mathrm{i}$ »divljih« nacionalizama, također je otvoreno pitanje na koje ne možemo odgovor potražiti u Bolčićevu, ali ni drugim djelima. Možemo se jedino misaono pridružiti njegovim iznimno promišljenim, poticajnim i cjelovitim pretpostavkama za demokratsku i ekonomski uspješnu rekonstituciju društva (Srbije, ali i brojnih drugih sličnih /»tranzicijskih«/ društava). Koliko su te pretpostavke ostvarive, pokazat će se u ne tako dalekoj budućnosti (/pre/daleka budućnost više daje šanse istrajavanju postojećeg nego izgradnji boljeg društva). A na pitanje kako ćemo nazvati bolje društvo, razvojno-ekonomski uravnoteženo, tolerantno prema drugima i de- 
mokratski uhodano, ne libeći se u kulturnodemokratsku baštinu tog društva uvrstiti i ažuriranu Lenjinovu poruku o »nacionalnom obliku« i »socijalističkom sadržaju« - najbolji odgovor još uvijek pruža Shakespeareova figura o »mirisu ruže«. ${ }^{11}$

\section{LITERATURA}

Bolčić, Silvano (2013). Razaranje i rekonstitucija društva: Srbija na prelazu u XXI vek. Beograd: Službeni glasnik.

Brubaker, Rogers (2002). »Ethnicity without groups«, European Journal of Sociology / Archives Européennes de Sociologie, 43 (2): 163-189. doi: 10.1017/ S0003975602001066

Flaschel, Peter i Luchtenberg, Sigrid (2012). Roads to Social Capitalism: Theory, Evidence, and Policy. Cheltenham: Edward Elgar Publishing.

Gellner, Ernest (1998 [1983]). Nacije i nacionalizam. Zagreb: Politička kultura.

Hastings, Adrian (2003 [1997]). Gradnja nacionaliteta. Rijeka: Adamić; Sarajevo: Buybook.

Herzog, Philipp (2010). »'National in form and socialist in content' or rather 'Socialist in form and national in content'?: The 'amateur art system' and the cultivation of 'folk art' in Soviet Estonia«, Narodna umjetnost, 47 (1): 115-140.

Kalanj, Rade (2010). Ideologija, utopija, moć. Zagreb: Jesenski i Turk.

Katunarić, Vjeran (2003). Sporna zajednica: novije teorije o naciji i nacionalizmu. Zagreb: Jesenski i Turk i Hrvatsko sociološko društvo.

Katunarić, Vjeran (2007). »Traditionalism, Modernism, Utopianism: A Review of Recent Works on Transition in Croatia«, Politička misao, 44 (5): 3-27.

Lenjin, V. I. (1977). Socijalizam i nacionalno pitanje (izbor tekstova i predgovor Rade Kalanj). Zagreb: Školska knjiga.

Marx, Karl i Engels, Friedrich (1978). Rani radovi. 6. izd. Zagreb: Naprijed.

Mežnarić, Silva (1993). »The rapists' progress: ethnicity, gender and violence«, Revija za sociologiju, 24 (3-4): 119-129.

Rus, Veljko i Adam, Frane (1989). Moć i nemoć samoupravljanja. Zagreb: Globus. Shakespeare, William (2007 [1597]). Romeo i Julija. Zagreb: Mozaik knjiga.

[Weber, Max] Veber, Maks (1964). »Nauka i politika«, u: Mihailo Đurić. Sociologija Maksa Vebera. Zagreb: Matica hrvatska, str. 177-197.

\footnotetext{
${ }_{11} »$ Ime nije ništa; ono što nazivamo ružom, slatko bi mirisalo i s drugim imenom« (Shakespeare, 2007 [1597]).
} 